\title{
THE UNITED STATES AND THE EUROPEAN UNION: TRANSATLANTIC RELATIONS, MULTILATERALISM AND INTERNATIONAL STABILITY *
}

\section{Meltem MÜFTÜLER-BAÇ** Damla CİHANGİR-TETÍK ${ }^{* *}$}

\section{Abstract}

What role does the European integration process play in shaping transatlantic relations, if any? The question brings forth the related issue of whether the EU is able to exercise leadership in fostering changes in the international system and through its relationship with the US. The article provides a literature review on the EU as a foreign policy actor, specifically the extent to which it contributed to changes in the international system along a multipolar pattern. To do so, it looks at the EU's ability to strengthen multilateralism in international trade and its role in international security. The article's analysis of the EU and its ability to speak with one unified voice is significant in understanding the EU's role in Transatlantic relations and its ability to become player on its own right with regard to the US in international politics.

Keywords: Transatlantic relations, European integration, EU, international trade, international security, multilateralism

\footnotetext{
* This paper emanates from a European Commission SSH research Grant under its $7^{\text {th }}$ Framework Program: "Transworld: The Transatlantic relationship and the Future of Global Governance". We would like to thank John Peterson, Michael Smith, Nathalie Tocci, Riccardo Alcaro, Michelle Egan and Maria Green Cowles for their comments and suggestions on earlier drafts of the paper.

${ }^{* *}$ Prof. Dr. Jean Monnet Chair, Sabanc1 University, Faculty of Arts and Social Sciences, Department of Political Science, e-mail: muftuler@sabanciuniv.edu

${ }^{* * *} \mathrm{PhD}$ Candidate, Sabanc1 University, Department of Political Science, e-mail: damlac@sabanciuniv.edu
} 


\section{AMERIKA BİRLEŞİK DEVLETLERİ VE AVRUPA BİRLİĞİ: TRANSATLANTIKK ILIŞSILER, ÇOK TARAFLILIK VE ULUSLARARASI İSTIKRAR}

\section{$\ddot{O} z$}

Avrupa entegrasyon süreci, eğer herhangi bir rol oynuyorsa, transatlantik ilişsilerin biçimlenmesinde hangi rolü oynuyor? Bu soru, AB'nin uluslararası sistemdeki değişiklikleri teşvik etmede ve ABD ile olan ilişkisi yoluyla liderlik edebilip edemeyeceği konusunu ortaya koyuyor. Makale, AB'nin özellikle uluslararası sistemde, çok kutuplu bir biçimde meydana gelen değişikliklere katkıda bulunduğu ölçüde, bir dış politika aktörü olması üzerine bir literatür taraması yapıyor. Bunu yapmak için, AB'nin uluslararası ticarette çok taraflılı̆̆ güçlendirme kabiliyeti ve uluslararası güvenlikteki rolüne baklyor. Makalenin $A B$ analizi ve AB'nin birleşik bir sesle konuşma yeteneği, AB'nin Transatlantik ilişkilerdeki rolünü ve uluslararast siyasette $A B D$ 'ye rağmen kendi başına bir oyuncu olabilme becerisini anlamada önem taşıyor.

Anahtar Kelimeler: Transatlantik ilişkiler, Avrupa entegrasyonu, AB, uluslararası ticaret, uluslararası güvenlik, çok taraflılık

\section{Introduction}

In the recent years, the Transatlantic relations suffered as a result of an European economic crisis, declining defense budgets in Europe, disagreement over security risks and the proper responses to them, the war on terrorism, and collapse of authoritarian regimes in the Middle East. Whether the Transatlantic partnership between the United States and the European Union would remain intact and continue to prosper emerged as a critical question. However, the partnership between the European countries and the United States played a critical role in shaping global order in the post 1945 world order. The US and its European allies, representing the 'West', were the main force behind the international financial order, the free trade system and the collective security 
arrangements. The United Nations, the General Agreement on Tariffs and Trade (GATT) regime, and the Bretton Woods system comprising the International Monetary Fund (IMF) and the World Bank, all have roots in the 'West', and the 'West' achieved through them a leadership status which the Soviet-led Communist bloc was never able to match fully (Keohane, 2002). It is within this framework of global governance that the possible impact of the European integration process on transatlantic relations needs to be assessed.

Particularly important here is whether the EU has exercised any form of leadership in its relations with the USA and in fostering international cooperation. Within this context, the extent to which the EU contributed to changes in the international system along a multipolar pattern has been critical in Transatlantic relations. Accordingly, this article focuses on the EU's ability to strengthen multilateralism in international trade and its role in international security as policy areas where European integration might have impacted Transatlantic relations. The European Union's ability to act as a partner of equal rank in its relations with the US depends on the emergence of one unified voice for the EU.

José Manuel Barroso, former President of the European Commission, summarized this view as: "Europe needs the US and the US needs Europe. When we speak with a common voice, no challenge is too great. When we speak with a common voice, we are truly an indispensable partnership". ${ }^{1}$

This brings us to the following questions: What role exactly does the European integration process play in shaping transatlantic relations? Does it drive them towards greater or lesser cohesion? Has the EU exercised leadership in fostering changes in the international system and in its relations with the US? Specifically, is EU integration shaping transatlantic relations along a structural drift, a functional partnership or an enduring partnership pattern (Tocci and Alcaro, 2012)?

On the economic front, the introduction of the euro, the EU's single position in the World Trade Organization (WTO), the European power in the G8 and G20 (where the EU is present also on an autonomous basis) and the

\footnotetext{
${ }^{1}$ Commission of the European Communities (2006) "The European Union and the United States. Global partners, global responsibilities", http://www.eurunion.org /partner/ euusrelations/EUUSGlobParts.pdf.
} 
international financial institutions (IFIs) (Meunier, 2000; 2005) and ongoing TTIP (The Transatlantic Trade and Investment Partnership) negotiations between the EU and US are cases where the EU has exercised leadership both in strengthening multilateralism (Tocci, 2007), and through its relationship with the US. On the security side, the development of the Common Foreign and Security Policy (CFSP) and the European (now Common) Security and Defence Policy (ESDP/CSDP) as well as of the EU's external development and cooperation policy, alongside external developments such as crisis management in the Balkans, the Iraqi War, the Libyan Crisis, relations with Russia and Iran's nuclear programme are all issues on which EU member states have found themselves struggling between their wish to keep a united front, and the priority, at least of some member states, not to alienate the US. These emerge as policy areas where the EU's ability to exercise leadership remained limited (Smith, 2006), and the EU as a whole did not significantly contribute to international changes (Bickerton, 2011; Hollis, 2012). Furthermore, in the post 9/11 period, in matters of internal security, counterterrorism has emerged as an area where EU integration has forced a reappraisal of relations with the US within EU member states (Howorth and Menon, 2009). There are, of course, other issues such as environmental protection or the International Criminal Court (ICC), in which the EU did exercise some leadership and contribute to international changes that shaped the policy outcomes (Howorth, 2010). This article cannot address all of these issues. It instead narrows down its focus to trade policy - an area where European integration has been the most extensive with the EU exercising leadership role in fostering multilateralism on the one hand and contribute to the creation of a multipolar world on the other hand (Smith, 2004; Peterson and Steffenson, 2009); and the EU's foreign, security and defence policy - an area where progress in European integration has lagged well behind (Sjursen, 2011; Hill, 2003) thereby limited the EU's leadership role both internationally and in terms of its relations with the US.

In this context, it is important to keep in mind that transatlantic relations and the process of European integration are both affected from the emerging global balances of power (Kopstein and Steinmo, 2008). The political and economic conditions that have enabled the EU and the US to act as global leaders are 
fading, ${ }^{2}$ although the ability of rising powers to challenge the Western-shaped and -dominated liberal order remains an open question (Hart and Jones, 2010; Howorth, 2010). The rising powers such as China, India, and Brazil, as well as a resurgent Russia, contest the rules that the transatlantic partners have drawn up as well as their ability to decide on the fate of global governance. The economic crisis and the decline in the credibility of Western economic models world further exacerbated this situation. It is also within this changing international context that the EU's leadership abilities to strengthen multilateralism or contribute to a multipolar world might remain limited.

In order to assess the potential future of transatlantic relations, this article first looks at the institutionalization of the EU-USA partnership, and then it investigates the implications of EU trade policy for transatlantic relations and multilateral governance as well as the evolution of the EU as a foreign policy actor in the realm of international security and defence issues. The article compares the evolution of EU's foreign, security and defence policy with its trade policy in order to clarify their impacts on Transatlantic relations and the EU's contribution to multilateral governance in these specific areas. By doing so, the article aims to provide an overview of the EU's ability to strengthen multilateralism, its role as a foreign policy actor in the building of a multipolar world and the institutionalization of its relations with the USA.

\section{The Institutionalization of Transatlantic Relations}

The deepening of integration over time has impacted the EU's role both in building a multipolar world and in its relations with the USA. Even though the early years of integration were uneasy (Green Cowles and Egan, 2012), the EEC began to symbolize a post-national political aspiration. The US, which had granted diplomatic recognition to the ECSC already in 1953, continued to back the integration process as a powerful instrument to ensure political stability and foster prosperity in West Europe. ${ }^{3}$ Since the 1990s, the US and the EU have established a framework for dialogue and cooperation partly in response to the process of European integration and the institutionalization of the EU-US

\footnotetext{
${ }^{2}$ Their combined share of global wealth has steadily declined from 52 percent in 1990 to 40 percent in 2011.

${ }^{3}$ For a chronological detail of the main documents of USA-EU relationship, see the European External Action Service page on the USA, http://eeas.europa.eu /us/index_en.htm.
} 
relations slowly evolved since then. The EU's role is strengthening multilateralism through its relations with the USA is summarized by the former Commissioner for External Relations Benita Ferroro-Waldner in 2005 as: "In a world of global threats and challenges, global markets and global media, our security and prosperity increasingly depend on an effective multilateral system". ${ }^{4}$ First, the institutional reforms increased the EU's ability to act as an equal partner vis-à-vis the US (Smith, 2011) on certain issue areas such as trade, environment and competition. This meant that the EU contributed to strengthening multilateralism in international politics with regards to these issues. That is because, "a divided Europe has no say, but a united Europe has a real opportunity to be a driving force in the sound management of globalization" (Gnesotto, 2010: 30). As size is an important indicator of market power (Damro, 2012), the EEC became one of the most important global players in international trade (Meunier and Nicolaidis, 2006). Specifically, the integration process enabled the adoption of bilateral diplomatic tools such summit diplomacy. The first step in this regard came in 1990 with the Transatlantic Declaration and the EC/EU and US annual summits, signaling the American acceptance of the EC as an equal partner. ${ }^{5}$ What is more, the Transatlantic Declaration elevated the European Commission's role in transatlantic relations, which coordinated the EU's representation in the regular meetings between the EU and US officials on almost all areas of joint concern. This meant that the declaration created a Transatlantic Dialogue which became the most important mechanism for EU-US deliberations.

An additional step was taken in 1995 with the New Transatlantic Agenda (NTA), which committed the parties to the overall objectives of promoting societal exchanges, deepening economic relations and strengthening political cooperation (Steffenson, 2005). The NTA created a new institutional framework for presidential meetings and spelled out the modalities of cooperation and consultation for technical working groups. The NTA could be seen as an outcome of the European integration process on the one hand and the EU's ability to strengthen multilateralism in international politics on the other. At the same time, one could conceptualize both the Transatlantic Declaration

${ }^{4}$ The European Commission, The European Union and the USA, Global Partners, Global Responsibilities, Brussels, 2005, p.16.

${ }^{5}$ Transatlantic Declaration on EC-US Relations, November 1990, http://eeas.europa.eu/ us/index_en.htm. 
and the NTA as attempts by the US and the EU to deal with the increased uncertainty of the post-Cold War period, cementing their already strong relations under NATO with cooperation in other areas (Pollack, 2005).

The next step in the institutionalization of transatlantic relations came in 1998 following the path already set forth by the NTA. The EU's unified position as a partner for the US became apparent with the adoption of Transatlantic Economic Partnership (TEP) at the EU-US London summit of 18 May 1998. Most importantly, the EU and the US adopted a plan to be carried out by the US administration and the European Commission for developing the modalities of further cooperation as well as coordination of the parties' respective positions in international organizations. The adoption of the NTA and the TEP signaled that European integration had reached such a point that the EU's main executive body, the Commission (rather than member state executives), would act as counterpart to the US, specifically on trade related matters (Elsig, 2007). In 1999, a new framework of consultation was established with the launch of the Transatlantic Legislators' Dialogue, involving regular consultations between the members of the European Parliament (EP) and the US Congress. The transatlantic relations, then, were further shaped with the establishment of the Transatlantic Economic Council (TEC) in 2007, charged with coordinating economic cooperation between the two shores of the Atlantic. Pollack and Shaffer (2010) summarize this increased visibility of the European Union institutions in Transatlantic relations and the EU's ability to strengthen multilateralism through the 'leading intergovernmental role played by the European Commission'. Thus, the institutionalization of EU-US relationship throughout the 1990s could be seen as extension of the EU's role in building a multipolar world, as "the EU's multilateral activities are a natural extension of the Union's own example of integration through pooled sovereignty" (Mahncke et al., 2004: 136).

Since 2012, a new momentum was gained in the Transatlantic policy with the partnership dialogue on trade policy, the TTIP... The TTIP aims to deepen Transatlantic trade relations and establish the world's biggest Free Trade Area by abolishing tariff barriers and reducing other non-tariff barriers. TTIP will not only change Transatlantic trade relations, it will also affect international trade, global trade relations and income of the rest of the world. TTIP is another global development that the EU is represented by the European Commission on an equal footing with the US. 
Despite the institutionalization of Transatlantic relations over time, the internal complexities in the integration process impact the EU's ability to play a leadership role in international politics. This was clearly seen in 2010 when US President Barack Obama rejected an invitation to a summit organized by the Spanish EU presidency at the time, based on the formal argument that the presidency no longer represented the EU under the Lisbon Treaty. ${ }^{6}$ Instead, the US President participated in the EU-US Summit in November 2010, which was organized by then newly elected European Council president Herman Van Rompuy. This incident illustrated the reflection of the internal complexities in the EU's institutional dynamics onto the Transatlantic relations.

The institutional reforms adopted over time aimed to address precisely that problem. For example, the changes introduced by the Lisbon Treaty mean that the HR and the EEAS negotiate in the name of all EU member states in major international conferences. In addition, in specific areas such as climate change, the European Commission is the main negotiator (Bendiek, 2012). The impact this could have on transatlantic relations could echo that of the SEA, since EEC/EU-US summits became possible precisely because the SEA created a single voice for EU members on all matters related to trade (Meunier, 2000; 2005). One could see this as a clear illustration of the EU's leadership capabilities in strengthening multilateralism.

Transatlantic economic relations are the strongest in the world, ${ }^{7}$ both in terms of their institutional arrangements and in terms of the volume of exchanges. The path of European integration, precisely because it was guided by economic integration, has deeply shaped transatlantic economic relations (Steffenson, 2005). A strong, unified Europe undoubtedly strengthens the transatlantic economic ties by offering American firms and investors a large, open market with which to trade and in which to invest. At the same time, since its ultimate goal is to make war materially impossible on the European continent, the European integration process influences the security dimension of transatlantic relations (Peterson and Steffenson, 2009). It is because of these

\footnotetext{
${ }^{6}$ Kramer, N. P. (2010) "The US State Department cites confusion caused by the Lisbon Treaty's new institutional arrangements for the President's absence from the Summit", European Business Review, 5 February, http://www.europeanbusinessreview.eu/ page.asp?pid=714.

${ }^{7}$ For further empirical data see Green Cowles and Egan 2012.
} 
ties between the EU and the USA that European economic crisis since 2008 impacts both players. The economic crisis in the EU, with the sovereign debt problems and declining economic growth, is particularly important for the US. The EU's role in building a multilateral and multipolar world has been more visible and critical in Transatlantic economic relations, rather than security and defence policies.

\section{European Integration and Transatlantic Economic Relations}

For decades, if not centuries, the West has constituted the most powerful economic bloc on the planet. Today, the combined economies of the US and the EU represent roughly around 45 percent of the world's GDP (World Bank, 2014) and they are each other's most important trade and investment partners (Sbragia, 2010). One could also point out that the EU-US economic relationship is 97 percent dispute-free. It comes as no surprise then that the two are largely responsible for shaping global economic interactions and governance structures. This is also reflected by Jacoby and Meunier (2010) in their claim that the EU's economic integration has enabled it to 'manage globalization' by empowering international institutions. The US and EU countries (provided they act in unison) are still the most influential members of the main institutions of the global economy, the IMF, the World Bank and the WTO. Specifically, trade has emerged as the one area where European integration is most visibly felt in the transatlantic relationship (Elsig, 2007). The EU's trade policy establishes common rules, including common custom tariffs, a common import and export regime, and uniform trade liberalization and protection measures. The common trade policy of the EU requires member states to harmonize and decide common measures for their external trade policies in order to achieve the targets for the EU's internal market (Meunier, 2000). Thus, the EU's trade policy has evolved in a supranational way instead of remaining as intergovernmental.

The most impressive achievements of European integration in the field of economics are the creation of the Single Market with the 1986 Single European Act and the adoption of a single currency, the euro, in 1999. These have also turned out to be the areas of European integration that have most significantly impacted both global governance and transatlantic relations. The 1986 Single European Act was a milestone in European economic integration (Damro, 2012). In the 1980 s at the time EEC member states were experiencing a 
downturn. Not only did the SEA boost the economies of the ECC member states, it also enabled the EEC (after Maastricht simply European Community, EC) to emerge as a single player in WTO trade negotiations. In particular, the EC partnered with the US in the Uruguay Round, contributing to the creation of the WTO in 1995 (Meunier and Nicolaidis, 2006).

As the EU has expanded its legislative reach in trade and internal market, it has acquired responsibility from its individual member states for negotiating with third parties and being represented in international forums. As a result, the EU and its member states engage in a complex internal negotiating process before they participate in any international negotiation. This process takes place in the Council, through a specialized body, the so-called the Article 133 Committee, preparing its decisions on trade. European trade integration received a new boost with the Lisbon Treaty, which has given the EP additional jurisdiction over trade matters. Trade agreements authorized by the European Council and negotiated by the European Commission (which retains the right to propose and draft EU legislation) now require the approval of both Council and the EP before entering into force. The Parliament is now a new force to be reckoned with in trade-related issues. As a result, the EU integration in the economic field has gradually empowered EU institutions with ever more incisive instruments to deal with the US.

Even though the EU's power at the WTO as a single actor, representing all its Member States, empowers the EU in shaping multilateral trade negotiations, Transatlantic relationship and during the negotiations with third countries, deadlock in multilateral trade talks since Doha Round in 2001 leads the EU to search for new regional and bilateral trade agreements as alternatives. Especially since 2006, the EU has focused on more regional and bilateral Free Trade Agreements (FTAs) with third countries. The EU aimed to play an active role in promoting its trade policy by concluding ambitious new generation FTAs with third countries, which are strategically important trade partners with, have substantial economic size and growth rates. These new agreements negotiated by the EU aim the reduction of tariffs on industrial and agricultural goods but also the liberalization of trade in services and the elimination of nontariff barriers so as to gain better access to these potential markets (Evenett 2007, Young and Peterson 2006). Also, with the Lisbon Treaty, the context of these new generation of FTAs has become much more comprehensive as they cover trade in services, investment, public procurement, IPR, competition, trade 
and sustainable development, economic and technical cooperation, which were not included in previous trade agreements. In this context, the EU paid particular attention to the economically rising powers of Asia towards where the centre of world production has been moving and to countries such as China, India and South Korea, which will play an even greater role within the global supply chain (Decreux, Gouel and Valin, 2009).

Until today, the EU concluded preferential trade agreements with 53 countries and is in the process of negotiating with 80 countries $^{8}$. There is no doubt that new generation of the FTAs have strengthened the EU's global economic actorness and increased the competitiveness of transatlantic trade relations. However, WTO's stalled Doha Round and the rising economic powers, such as China, India, and Brazil, motivated the transatlantic partners to move beyond their existing bilateral preferential agreements with third countries and establish a bilateral preferential trade-plus agreement with each other, the TTIP.

In 2012, the EU and the US started to negotiate TTIP, which is an ongoing detailed process in several sectors in order to deepen transatlantic trade to deal with the economic challenges of the $21^{\text {st }}$ century. The European Commission stated that an ambitious TTIP deal would increase the size of the EU economy around $€ 120$ billion (or $0.5 \%$ of GDP) and the US by $€ 95$ billion (or $0.4 \%$ of GDP). This would be a permanent increase in the amount of wealth that the European and American economies can produce every year (European Commission 2013).

"The EU and the US are relatively open towards each other in terms of investment and trade, as reflected in relatively low levels for tariffs. However, various non-tariff barriers -NTBs- (often in the form of domestic regulations) on both sides of the Atlantic constitute important impediments to transatlantic trade and investment flows. Even though they might not be directly targeting cross-border activities they nevertheless do bear a cost on trade and investment. The reduction of such barriers could potentially benefit both the EU and the US." (Francois 2013, 7). TTIP negotiations could be considered as one of the success stories of European integration in economy and trade policy, where the

${ }^{8}$ European Commission, DG Trade web site, http://rade.ec.europa.eu /doclib/docs/ 2012/june/tradoc_149622.jpg 
EU as a single body negotiates with the US and the agreement would impact multilateral governance structures of the world in economy and trade related matters.

The fact that the EU speaks with a 'single voice' in trade has enabled it to affect the distributional outcomes of international trade negotiations and shape the global political economy. In this case, international bargaining power has been a positive externality of the pooling of the diverse European national positions on trade under a single institutional umbrella (Meunier 2005:2).

This, in turn, increases the relative power of the Union in international trade negotiations. The EU's remarkable power in international trade arrangements, however, has also resulted in clashes with the US, some of them of a bitter nature, within the WTO. As such:

The EU is currently the world's largest trader and one of the main players involved in negotiating trade agreements as part of the ongoing Doha Development Round under the WTO. This provides opportunities for further transatlantic trade conflicts, as do the numerous EU-U.S. disputes under consideration at the WTO, such as those on Genetically Modified Organisms and on tax breaks on exports (Meunier, 2005: 4). ${ }^{9}$

It is primarily the EU's presence in the WTO, but also the EU's success in concluding several preferential trade agreements and FTAs with third countries and finally, the launch of TTIP negotiations between the EU and the US that one can pinpoint as critical illustrations of the impact of European integration on transatlantic relations, as well as the EU's impact on strengthening multilateralism and multipolarity. Yet, this was not the only consequence of the great leap forward in economic integration brought about by the SEA and the Maastricht Treaty.

Throughout the six decades since the end of the Second World War, the US and Europe prospered together in an unprecedented fashion. However, they now face challenges that might obstruct the path of shared prosperity they have been following for so long. The 2008-09 financial crisis and the subsequent debt crisis in some EU member states cast a long shadow over the future of transatlantic economic relations (Underhill, 2011). Furthermore, declining

\footnotetext{
${ }^{9}$ It should be noted that by early 2012, it appeared that the Doha Round was dormant, if not dead altogether.
} 
economic growth rates and static or negative population growth in Europe do not bode well for the continued pre-eminence of the EU in global economics. This would represent a major watershed in contemporary world history, given that the EU is still the world's largest economy, with a combined GDP of its member states worth $\$ 18$ trillion annually.

If the advancement in European integration in the 1990s resulted in the EU's greater bargaining power vis-à-vis the US, it would be rational to expect that with decreasing momentum in European integration, there would be an inevitable downturn in transatlantic relations. When one looks at the main dynamics of interaction between the EU and the US, two main factors emerge accounting for their ability to shape global governance: their joint share in global economy and their combined control of the international institutions. Yet, there are drastic changes in both. In 2000, the member states of the Organization for Economic Cooperation and Development (OECD), which brings together the advanced economies of the West, accounted for 55 percent of the global wealth, and the Asian countries only about 24 percent. By 2025, the OECD countries share will go down to 40 percent and Asian countries will have a share of around 38 percent, and the balances will continue to tilt towards east. ${ }^{10}$ The demographic shifts also attest to that, as by 2025 around 45-50 percent of the world's population is predicted to be Asian.

This global transformation poses three pressing issues for the future of transatlantic relations. From an economic perspective, it is essential to assess the implications of the relative economic decline in Europe-US and their share of global welfare, while from a political perspective, since the US and the EU were the main actors behind international institutions, it remains to be seen whether the US' and EU's relative decline in economic wealth and population will translate into a loss of political clout. Furthermore, the declining economic performance of the EU members since 2008 by the Euro zone crisis could make the US turn towards the Pacific Rim countries, particularly those on the Asian side of it, which have been experiencing an economic boom for years.

If the economic performance of EU members continues to decline, the EUUS economic relationship might also loosen (Jacopy and Meunier, 2010). Alternatively, the EU-US economic partnership, TTIP might also deepen with

10 "Developing countries to eclipse the West", Guardian, 9 November 2012 
the adoption of such measures as a free trade area-currently under negotiationsin order to deal with the challenges posed by the global economic crisis. The fate of their partnership also rests with the EU's ability to mend internal strife among its members and act as a unified bloc once again. The economic side of the transatlantic relationship seems then to indicate that their relationship could be seen as an 'enduring partnership'. This is in sharp contrast with the foreign and defence policies of the Transatlantic partners. While trade as a policy area is managed collectively by the EU institutions, foreign, security and defence policies are still subject to intergovernmental bargaining (Peterson, 2004; Steinberg, 2003; Smith, 2006). The EU's evolution as a foreign policy actor emerges as an issue area where the EU's leadership in both strengthening multilateralism and through its relations with the USA remain limited, as is addressed in the next section.

\section{Transatlantic Security Cooperation: The role of intergovernmentalism}

Despite many years of institutional deepening, European integration in security and defence matters still remains intergovernmental (although we also need to keep in mind that European foreign policy - defined in a broad sense extends to trade policy as well, so the discussion in the above section sheds light on European foreign policy). The EU's evolution as a foreign policy actor emerges as a critical factor in its leadership ability in international politics, specifically through its relations with the USA. The EU over time has expanded its position in the international system and "forged a relationship with a great number of multilateral organizations and became a party, usually with the member states, to a huge number of international agreements: 249 multilateral treaties and 649 bilateral treaties are recorded in the European Commission's data base of treaties" (Emerson and et al, 2011:11).

Yet, in the realm of security and defence policy transatlantic relations are best reflected under the NATO framework, where only 22 EU Member States are individual members of NATO and there is not a single EU representation. Even though European integration in security and defence policy enabled the creation of the CSDP, it has not become a sufficient tool for 28 Member States to act unified during the recent global security and military crises (Toje, 2008), and to cooperate with the US in an equal footing. In addition, relations between 
the NATO and the EU remain problematic. ${ }^{11}$ In part, this is a reflection of the lack of a strong consensus within the EU about how far EU defence integration should go, and how autonomous from NATO it should be.

The evolution of the EU as a foreign policy actor received a significant boost with the Lisbon Treaty which aimed at both remedying the flaws in the institutional and capability structure in European foreign policy, and providing willing and able member states to bring defence integration forward in smaller groups through the 'permanent structured cooperation' mechanism. Yet, permanent structured cooperation has never been made use of until now. When it comes to foreign and security policy, the reflex in the US is to seek cooperation with European countries on a bilateral basis or within NATO (Peterson and Steffenson, 2009; Howorth and Menon, 2009), as the underresourced, under-equipped and unanimity-based CSDP offers little incentives to connect with (Thomas, 2012). In addition, the EU's single voice in international institutions such as the UN (Smith, 2006) is still problematic as some EU members such as the UK and France hold on to symbols of their power status, notably their permanent seat - with the associated veto right - in the UN Security Council. This in turn limits the EU's ability to act as a leader in strengthening multilateralism as well as in its relations with the USA.

In the recent years, the Union found itself confronted with significant common foreign policy issues, ranging from the 2009 Copenhagen summit on climate change (Szarka, 2012), the 2010 Arab Spring, from the 2011 Libya crisis to the recent Syrian refugee crisis. Among all of the global political crisis, the single voice and collective European interest is clearly seen with the EU's full membership in the G20 and the G8 where it is co-represented by the Presidents of the European Commission and European Council. The EU's presence in the G20 is such that the President of the European Council tends to present the EU in foreign policy matters and the European Commission President on matters relating to the EC competence. The G8 and G20 summits have become international platforms for the EU where it can provide concrete solutions to the existing global economic and foreign policy challenges, such as the global economic downturn, the consequences of the Arab Spring or the Iraqi

11 A major obstacle in further cooperation between NATO and the EU is the complications arising from the Cyprus problem. 
War and the recent refugee crisis. In the G8 summit in May 2012, and the G20 summits in June 2012 and October 2015, the EU representatives put together joint EU positions for further economic cooperation at the global level and signaled the EU's commitment to overcome global economic challenges, ${ }^{12}$ aiming for a leadership role for the EU in promoting multilateralism and multipolarity. Since 2010, prior to G20 summits, the EU officials try to coordinate both within the EU institutions and member states and formulate a common EU position. This, in turn, increases the EU's visibility as a leader in promoting multilateralism in economic issues. A similar path could be foreseen for the foreign, security and defence policies which would then transform the EU into a credible partner for the US in international security matters as well. Yet, the past experiences in this regard have not been promising (Tonra, 2011).

A clear illustration of these complexities in American-EU security cooperation came with the US-led intervention in Iraq in 2003. While the debate was commonly presented as an exchange between the US and Europe (Stevenson, 2002), in fact it was very much an internal EU debate (Steinberg, 2003). The UK, Spain, Italy, Portugal and Denmark, as well as the then candidate countries from Central and Eastern Europe, sided with the US whereas France, Germany, Belgium and Luxembourg, along with a significant majority of the EU's public, were very critical of the intervention. The intra-EU split demonstrated that security and defence cooperation in the European Union was still fragile and could crumble down at the first major crisis (Yost, 2002). Even though, the split within the EU originated from disagreement over the intervention in Iraq, the lack of cohesion among the EU members on a major international event highlighted the role of divergent member states' preferences on foreign policy, and specifically on military cooperation with the US (Hill, 2003; Howorth and Menon, 2009). These internal divisions limited the EU's leadership abilities in international politics (Hix, 2008). A similar illustration of the EU's lack of coordinated response in foreign and security policy issues could be found in the 2011 Libyan crisis (Hollis, 2012).

${ }^{12}$ Sherwell, P. (2012) "World leaders gather in the woods outside Washington for G8 summit", The Telegraph, 19 May, http://www.telegraph.co.uk/news/worldnews/ northamerica/usa/9277252/World-leaders-gather-in-the-woods-outside-Washington-forG8-summit.html. 
The Libya crisis erupted when the long-standing Libyan leader, Colonel Muammar Gaddafi, began to use force against rebels protesting against his dictatorial rule. The UN Security Council imposed sanctions against Libya, while an EU arms embargo was also adopted. In March 2011, the Arab League asked for a no-fly zone over Libya, which the UN Security Council authorized that same month, also giving the green light to the use of force (but not the deployment of troops on the ground) with the aim of protecting civilians. As had been the case with Iraq, EU member states failed again to forge a united front, with Germany going as far as to abstain from voting in favour of the Libya resolution put forward by its fellow EU partners the UK and France within the UNSC. Germany's abstention led some commentators to argue that "Germany has not only discredited itself as a reliable pillar of global security policy but it has also put paid to the fiction of an EU foreign policy on an issue of major global importance". ${ }^{13}$

The UK, France and the US formed an ad hoc coalition which only at a later stage, upon insistence by the US, Italy, the UK and other countries and against France's will, evolved into a NATO-led operation against Gaddafi's loyalists. Even so, only the UK, France, Belgium, Italy, Denmark and Norway, took active part in the air strikes. The US provided critical support but refrained from occupying the driver's seat in a Western military intervention abroad for the first time since the end of the Cold War.

France was undoubtedly the main force behind the Libyan intervention. However, the French also made a number of significant diplomatic mistakes in the attempt to secure their lead role. For example, Claude Guéant, the French interior minister, outraged the Muslim world by stating that the French president was "leading a crusade" to stop Gaddafi massacring Libyans. ${ }^{14}$ The French role in Libya caused frictions also with the Italians. Italian Prime Minister Silvio Berlusconi was initially opposed to an armed intervention in Libya $^{15}$ out of concern of losing Italy's privileged relationship with Gaddafi to

\footnotetext{
${ }^{13}$ Presseurop (2011) "European diplomacy disarmed", Presseurop.eu, 21 March, http://www.presseurop.eu/en/content/article/562781-european-diplomacy-disarmed.

14 Traynor, I. (2011) "Turkey and France clash over Libya air campaign", The Guardian, 24 March, http://www.guardian.co.uk/world/2011/mar/24/turkey-franceclash-libya-campaign.

${ }^{15}$ Pop, V. (2011) "Berlusconi exposes Libya rift within NATO", EUObserver, 8 July, http://euobserver.com/1016/113087.
} 
France's advantage. Once the operation was agreed upon, however, the Italians decided that it was better for them to go along with it rather than siding with Germany. Germany, in turn, tried to make up for its loss of credibility with its allies. The German Chancellor, Angela Merkel, eventually expressed "the deepest respect for NATO's involvement" ", making plain that Germany would go no farther than the adoption of political and economic sanctions. However, her declarations did little to hide the inability of the EU to act as a credible strategic actor even in its nearest abroad. The very fact that NATO (rather than CSDP) took the lead in Libya attests to this. As a result, the initial bickering among the EU members over the modalities of the action to be taken against Libya and the outright rejection by Germany in the UN Security Council illustrated the limits of integration in foreign and security policies.

The first observation over the Libyan crisis concerns the incoherence among the European states over their proper response (Hollis, 2012; Thomas, 2012). This was the moment when different preferences between the EU players became visible with respect to their preferred courses of action in the Middle East, and Libya illustrated the divergence among the EU members over common security action, as well as the limited role of the EU institutions, including the High Representative. The British position on Libya stressed the national interest of the country, rather than the European collective interest. British Prime Minister David Cameron declared the failure to act risked Libya turning again into "a pariah state festering on Europe's border, a source of instability, exporting terror beyond her borders. [...] So I am clear: taking action in Libya, together with our partners, is clearly in our national interest". ${ }^{17}$ The EU member states' emphasis on national self-interest to justify use of force, instead of a collective European interest is, nonetheless, telling. This is also reflected by the former French foreign minister Alain Juppé as: "The common security and defence policy of Europe? It is dead" (Garton Ash, 2011).

Over the Libya intervention, there seems to be at least some empirical verification of the hypothesis that no truly EU foreign policy will ever emerge

${ }^{16}$ DPA and AFP (2011) "Merkel praises NATO for Libya campaign", The Local, 27 August, http://www.thelocal.de/national/20110827-37221.html.

${ }^{17}$ Mulholland, H. (2011) "Libya: military action necessary, legal and right, says David Cameron", The Guardian, 21 March, https:/www.theguardian.com/politics/ 2011/mar/21/libya-military-action-necessary-david-cameron. 
if EU member states continue to anchor their foreign policy choices to a national interest-based perspective only. This means then when divergences between the member states over specific issues - ranging from security to trade - are reflected onto their bilateral relations with the US, the transatlantic partnership suffers. The internal bickering among the EU members sheds light on the relative lack of integration of European foreign and security policies, thereby decreasing the value of the EU as a security partner in transatlantic relations. On the other hand, the lack of cohesion among the EU members over collective decisions such as climate change, the Arab Spring or the recent migration crisis has limited the EU's leadership ability in strengthening multilateralism in international politics.

Yet, it is still possible that the future European foreign policy is not shaped by national interests but by an EU-level collective interest that transcends the material interests of the individual actors. The institutional changes brought by the Lisbon Treaty over EU's global role are steps along a more integrationist pattern. It is possible to see an amalgam of the different trajectories, where in certain areas such as human rights and human security, the EU institutions would take the lead and formulate a common position that the member states would adhere to. The EU's position on human rights in the United Nations as analyzed by Smith (2006) is a case in point. In this route, the member states would still retain the final say on the nature of the transatlantic relationship but the EU institutions would frame the general pattern of interaction and perform certain core tasks. This also fits into the argument that the likelihood of EU members' ability to ratify multilateral treaties is higher than non-EU members due to their institutional commitments (Elsig et al, 2011). This in turn would empower the EU's capacity in strengthening multilateralism in international politics.

Accordingly, foreign policy coordination within the EU could also signify that the EU-US relationship could be seen as an enduring relationship that also adapts to changing international conditions and transforms itself over time. The integration process proceeded in a relatively slower fashion in foreign policy making, especially in common security and defence policies; thereby the EU's role in constructing a multipolar world can be seen as less than satisfactory. In short, due to internal complexities in the evolution of the EU as a foreign policy actor, the EU's ability to act as a leader in strengthening multilateralism in 
security issues has been limited, and this is reflected in its relations with the USA.

\section{Conclusion}

This article argued that the European integration process has played a significant role in transatlantic relations. The EU's gradual evolution into a sui generis polity which incorporates state like characteristics with intergovernmental brakes ultimately means that in certain areas, the EU is able to act with a unified voice; in other areas, it can only produce a minimum common denominator among the many diverging preferences of its member states. The EU-US relationship has been greatly affected by this amalgam of supranational institutions and intergovernmental bargaining. The EU's role in international politics, specifically in such institutions as the WTO, G8 and G20, has been critical in strengthening multilateralism. At the same time, the EU through its relations with the USA enabled the emergence of a multipolar international system.

The most important aspect of European integration which has impacted the transatlantic relationship is precisely the pattern of transfer of competencies to the supranational bodies of the Union. The transfer of competencies and pooling of sovereignty has been the strongest in the areas of economic integration, particularly trade. The European economic and trade integration has proceeded far enough for the EU to be able to interact with the US on an equal footing. This has become a critical feature of transatlantic relations, specifically in such institutions as the WTO and in the EU's bilateral trade relations with the US. This enabled the EU to acquire the ability to foster multilateralism, particularly by building a capacity based on the cumulative strength of its 28 members. At the same time, since the EU became the world's largest internal market, it acquired the capability to influence global economic dynamics, in particular through its relations with the USA. The EU-USA acted together in tandem with global economic issues and in cooperation in the international financial institutions.

On the other hand, EU-US relations have not been trouble-free, especially with regard to foreign policy and security issues. The nadir in the transatlantic relations came with the 2003 Iraqi war, where the US seemed to emerge as a unilateral actor and the EU was paralyzed by internal disagreement over whether to join the invasion. The security dimension of transatlantic relations 
has been mostly shaped by NATO. The uncertain environment of the post-Cold War period led to the emergence of question marks with regards to NATO and the emergence of a European only vision for security within the EU. These developments have been particularly important in shaping transatlantic relations. Thus, when European integration spilled over to the field of foreign, security and defence policy, the internal complexities of the EU's role as a global actor and positions of EU member states have inevitably created new dilemmas for the Union. This is why the future of transatlantic relations partly depends on the EU's ability to become an accountable foreign policy actor as well as adopt the military capabilities and common decision-making procedures needed for an effective leadership.

In short, it seems that the different patterns of European integration in different policy areas impact transatlantic relationship and multilateral governance. This in turn provides us with empirical verification for the EU's ability to strengthen multilateralism in international politics through its integration process, but it also lends credibility to the proposition that the EU and the US relationship is evolving along an enduring partnership scenario. 


\section{References:}

Bendiek, A. (2012) "European Realism in the EU's Common Foreign and Security Policy", in P. J. Caldwell (ed.), EU External Relations Law and Policy in the Post-Lisbon Era, (The Hague: T.M.C. Asser Press), pp. 35-57.

Bickerton, C. J. (2011) European Union Foreign Policy from Effectiveness to Functionality, (Basingstoke: Palgrave).

Damro, C. (2012) "Market power Europe", Journal of European Public Policy, 19 (5): 682-699.

Decreux, Y., Gouel, C. and Valin, H. (2009) "The World in 2025: Economic projections with the MIRAGE model", in E. Faroult (ed.), The World in 2025 Contributions from an expert group, European Commission, pp. 311345 .

Elsig, M., Milewicz, K. and Struchler, N. (2011) "Who is in love with Multilateralism? Treaty Commitment in the Post Cold War Era", European Union Politics, 12 (4): 529-550.

Elsig, M. (2007) “The EU's choice of regulatory venues for trade negotiations: A tale of agency power?", Journal of Common Market Studies, 45 (4): $927-$ 948.

Emerson, M. et al. (2011) "Upgrading the EU's Role as Global Actor: Institutions, Law and the Restructuring of European diplomacy", CEPS paperbacks, 25 January, <http://www.ceps.eu/book/upgrading-eus-roleglobal-actor-institutions-law-and-restructuring-european-diplomacy $>$.

Evenett, S. J. (2007) "The Trade Strategy of the European Union: Time for a Rethink?”, Discussion Paper 2007-14, University of St. Gallen.

European Commission (2013) Transatlantic Trade and Investment Partnership The Economic Analysis Explained, <http://trade.ec.europa.eu /doclib/docs/2013/september/tradoc_151787.pdf\#world $>$.

Francois, J. (2013) Reducing Transatlantic Barriers to Trade and Investment: An Economic Assessment, CEPR Final Report, March, London. $<$ http://trade.ec.europa.eu/doclib/docs/2013/march/tradoc_150737.pdf $>$.

Garton Ash, T. (2011) "France plays hawk while Germany demurs: Libya has exposed Europe's fault lines", The Guardian, 24 March, 
$<$ http://www.guardian.co.uk/commentisfree/2011/mar/24/france-hawkgermany-demurs-libya-europe $>$.

Gnesotto, N. (ed.) (2010) Reshaping EU-US Relations. A concept paper, (Paris: Notre Europe), <http:/www.notre-europe.eu/en/axes/europe-and-worldgovernance/works/publication/reshaping-eu-us-relations-a-concept-paper>.

Green Cowles, M. and Egan, M. (2012) "The Evolution of the Transatlantic Partnership", Transworld Working Paper, No. 5, <http://www.transworldfp7.eu/?cat=13>.

Hart, A. F. and Jones, B. D. (2010) "How Do Rising Powers Rise?", Survival, 52 (6): 63-88.

Hill, C. (2003) The Changing Politics of Foreign Policy, (New York: Palgrave Macmillan).

Hix, S. (2008) What's wrong with the EU and how to fix it? (Cambridge: M.A: Polity).

Hollis, R. (2012) "No Friend of Democratization: Europe's Role in the Arab Spring”, International Affairs, 88 (1): 81-94.

Howorth, J. (2010) "The EU as a Global Actor: Grand Strategy for a Global Grand Bargain?”, Journal of Common Market Studies, 48 (3): 455-474.

Howorth, J. and Menon, A. (2009) "Still not Pushing Back, Why the European Union is not balancing the United States", Journal of Conflict Resolution, 53 (5) :727-744.

Jacopy, W. and Meunier, S. (2010) "Europe and the Management of Globalization”, Journal of European Public Policy, 17 (3): 299-317.

Keohane, R. O. (2002) "Ironies of Sovereignty: The European Union and the United States”, Journal of Common Market Studies, 40 (4): 743-765.

Kopstein, J.and Steinmo, S. (2008) Growing Apart?: Europe and America in the twenty-first century, (Cambridge: Cambridge University Press).

Mahncke, D., Rees, W. and Thompson, W. (2004) Redefining transatlantic Security relations, (Manchester: Manchester University Press).

Meunier, S. (2000) "What single voice? European institutions and EU-US trade negotiations", International Organization, 54 (1): 103-120. 
Meunier, S. (2005) Trading Voices. The European Union in International Commercial Negotiations, (Princeton: Princeton University Press).

Meunier, S. and Nicolaidis, K. (2006) "The European Union as a conflicted trade power", Journal of European Public Policy, 13 (6): 906-925.

Mulholland, H. (2011) "Libya: military action necessary, legal and right, says David Cameron", The Guardian, 21 March, $<$ https://www.theguardian.com/politics/2011/mar/21/libya-military-actionnecessary-david-cameron>.

O'Donnell, C. M. (2011) "Britain and France should not give up on EU defence co-operation", CER Policy Brief, October, $<$ http://www.cer.org.uk/publications/archive/policy-brief/2011/britain-andfrance-should-not-give-eu-defence-co-operation>.

Peterson, J. (2004) "America as a European Power: The End of Empire by Integration?", International Affairs, 80 (4): 613-629.

Peterson, J. and Steffenson, R. (2009) "Transatlantic Relations: Can Partnership be engineered?", British Journal of Politics and International Relations, 11 (1): $25-45$.

Pollack, M. A. (2005) "The New Transatlantic Agenda at Ten: Reflections on an Experiment in international governance", Journal of Common Market Studies, 43 (5): 899-919.

Pollack, M. A., and Shaffer, G. C. (2010) "Who Governs Transatlantic Relations", Minnesota Legal Studies Research Paper, No. 10-26 (May), $<\mathrm{http}: / /$ ssrn.com/abstract $=1600891>$.

Sbragia, A. (2010) "The EU, the US and trade policy: competitive interdependence in the management of globalization", Journal of European Public Policy, 17 (3): 368-382.

Sjursen, H. (2011) "Not So Intergovernmental After All? On Democracy and Integration in the European Foreign and Security Policy", Journal of European Public Policy, 18 (8): 1078-1095.

Smith, K. (2006) "Speaking with one voice? European Union co-ordination on human rights issues in the United Nations", Journal of Common Market Studies, 44 (1): 113-137. 
Smith, M. (2004) "Institutionalization, policy adaptation, and European foreign policy coordination", European Journal of International Relations, 10(1): 95-136.

Smith, M. (2011) "A liberal Grand Strategy in a realist world? Power, purpose and the EU's changing global role", Journal of European Public Policy, 18 (2) : 144-163.

Steinberg, J. B. (2003) "An Elective Partnership: Salvaging Transatlantic Relations”, Survival, 45 (2): 113-146.

Steffenson, R. (2005) Managing EU-USA relations, (Manchester: Manchester University Press).

Stevenson, J. (2002) "How Europe and America Defend Themselves", Foreign Affairs, 82 (2): 75-90.

Szarka, J. (2012) "The EU, the USA and climate divide: reappraising strategic choices", European Political Science, 11 (1): 31-40.

Thomas, D. (2012) "Still Punching below Its Weight? Coherence and Effectiveness in European Union Foreign policy", Journal of Common Market Studies, 50 (3): 457-474.

Tocci, N. (2007) "Profiling Normative Foreign Policy: The European Union and its Global Partners", CEPS Working Document, No. 279 (December), $<\mathrm{http}$ //www.ceps.eu/book/profiling-normative-foreign-policy-europeanunion-and-its-global-partners $>$.

Tocci, N. and Alcaro, R. (2012) "Three Scenarios for the Future of the Transatlantic Relationship", Transworld Working Paper, No. 4, $<\mathrm{http}: / /$ www.transworld-fp7.eu/?cat=13>.

Toje, A. (2008) “The Consensus-Expectations Gap: Explaining Europe's Ineffective Foreign Policy", Security Dialogue, (39) 1: 121-141.

Tonra, B. (2011) "Democratic Foundations of EU Foreign Policy: Narratives and Myths of EU Exceptionalism", Journal of European Public Policy, 18 (8): 1190-1207.

Underhill, G. R.D. (2011) 'Paved with Good Intentions: Global Financial Integration and the Eurozone's Response', European Political Science, 10 (3): 366-374. 
World Bank (2014) World Development Indicators Database, "Gross Domestic Product 2014", <http://databank.worldbank.org/data/download/GDP.pdf; accessed 20 February 2016>.

Yost, D.S. (2002) "Transatlantic Relations and Peace in Europe", International Affairs, 78 (2): 277-300.

Young, A. and Peterson, J. (2006) "The EU and the New Trade Politics", Journal of European Public Policy, 13 (6): 795-814. 